\title{
The concentrations of petroleum products in the waters of Lake Baikal and its tributaries during different seasons from 2010 to 2019
}

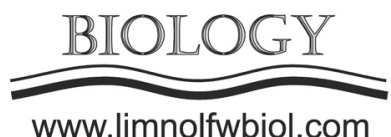

www.limnolfwbiol.com

\author{
Marinaite I.I.*, Zhuchenko N.A., Tomberg I.V., Onischuk N.A. \\ Limnological Institute, Siberian Branch of the Russian Academy of Sciences, Ulan-Batorskaya Str., 3, Irkutsk, 664033, Russia
}

\begin{abstract}
We present the materials on the concentration of petroleum products in the water of Lake Baikal and its tributaries from 2010 to 2019. Southern Baikal showed elevated concentrations of petroleum products. We revealed seasonal and interannual dynamics of concentrations of petroleum products in the tributaries of the lake. The bulk of petroleum products enters the rivers with the surface runoff of precipitation. We assessed the pollution degree of water in comparison with sanitary and hygiene standards.
\end{abstract}

Keywords: petroleum products, Lake Baikal, small and large tributaries.

Petroleum products are among the most widespread pollutants that affect human health and deteriorate the chemical and biological conditions in water bodies. The concentration of petroleum products should not exceed $100 \mu \mathrm{g} / \mathrm{dm}^{3}$ in drinking water (SanPiN, 2018), and $50 \mu \mathrm{g} / \mathrm{dm}^{3}$ (Prikaz..., 2018) in fishery waters. The surface runoff, accumulations of petroleum products in the snow and ice, the East Siberian and Baikal Amur railways, emissions from ship engines, and natural oil seepages onto the water surface are the sources of pollution by petroleum products.

Petroleum products were determined by the fluorimetric method. We have determined that the concentrations of petroleum products in the coastal water of Lake Baikal generally do not exceed maximum permissible concentrations (MPC) $\left(<5-56 \mu \mathrm{g} / \mathrm{dm}^{3}\right)$. The water in Southern Baikal had higher concentrations of petroleum products than that in Central and Northern Baikal. Were corded the minimum concentration sin Central Baikal. At the same time, the concentrations of petroleum products in all basins on the east coast of the lake were higher than on the west coast (Table 1). Analysis of surface and near-bottom samples revealed that the concentrations of petroleum products in the surface layer were 1.2 times higher than in the nearbottom one. In an interannual aspect, the highest concentrations of petroleum products were recorded in May 2017. That year, the vessel was moving behind melting ice and, perhaps, pollutants that accumulated in ice and snow over the winter caused an increase in the concentration of petroleum products. In the spring of 2018 and 2019, the concentrations of petroleum products in the lake water were close. In the pelagic zone, we determined the elevated concentration of oil products in the southern basin in 2019 as well as in the northern and central basins in 2017 (Table 1). In May 2019, at the pier near the Kultuk settlement, there was anincreaseinconcentrations 1.1 times exceedingMPC. As a rule, high concentrations of petroleum products are recorded at sites with natural oil seepages to the water surface. Thus, near Gorevoy Utes Cape, the concentrations of petroleum products reached extreme values of $300-1200 \mu \mathrm{g} / \mathrm{dm}^{3}$.

The concentrations of petroleum products in the large tributaries of Lake Baikal varied from $<5$ to 78 $\mu \mathrm{g} / \mathrm{dm}^{3}$ in the water of the Selenga River, from $<5$ to $18 \mu \mathrm{g} / \mathrm{dm}^{3}$ in the Upper Angara River and from 2 to 26 $\mu \mathrm{g} / \mathrm{dm}^{3}$ inthe Barguzin River. Higher concentrations of petroleum products are typical of spring floods, which is associated with their influx from the watershed with melt water. Elevated concentrations of petroleum products are most often observed near settlements. In the lower course of the Selenga River and its delta channels, the concentrations of petroleum products were regularly 1.5-2 times higher than MPC for fishery waters. Nevertheless, the annual average concentrations of petroleum products in the Selenga water was lower from 2010 to 2019 than from 1984 to 1988 (40-260 $\left.\mu \mathrm{g} / \mathrm{dm}^{3}\right)$.

In the rivers of Southern Baikal (the Utulik, the Solzan, the Khara-Murin, the Snezhnaya, and the Pereyomnaya), snow supply and late spring floods predominated from April to June. The maximum values of petroleum products were recorded in May and July, which is due to their influx from snowmelt and the watershed during rainfall. The rivers show elevated concentrations of petroleum products in the underice period (Table 2), which may be due to the works 
carried out upstream, leading to the flow of pollutants into river channels. MPC for fishery waters was 2.6 times exceeded in the Utulik River in July 2010, and 1.36 times -in the Khara-Murin River in July 2011. The waters in the Utulik, Khara-Murin and Snezhnaya rivers corresponded to MPC level in May 2010.

Small rivers on the southwest coast of the lake near the Listvyanka settlement experience the high anthropogenic pressure. The concentrations of petroleum products in the waters of these tributaries were higher than in the tributaries on the southeast coast of Southern Baikal. In March, with the onset of snowmelt, the concentrations of petroleum products abruptly increase. During this period, MPC was 2.215.6 times exceeded at the estuary of the Malaya Cheremshanka River, 14.2-15.8 times - at the estuary of the Bolshaya Cheremshanka River and 1.8-4.4 times - at the estuary of the Kamenushka River. During the summer tourist season, with an increase in road transport, we also recorded an increase in the concentrations of petroleum products at the estuaries of the Bolshaya Cheremshanka and Malaya Cheremshanka rivers.

Based on the 2010-2019 research, we revealed seasonal and interannual dynamics of the concentrations of petroleum products in the waters of the Baikal tributaries. The bulk of petroleum products enters the rivers with the surface runoff of precipitation. During snowmelt, the concentrations of petroleum products in large tributaries up to 2.6 times exceeded MPC, and in small tributaries - up to 15.6 times. In the water of Lake Baikal, we recorded elevated concentrations of petroleum products 1.1 times exceeding MPC in the surface water of the southern basin near the Kultuk settlement. The concentrations of petroleum products observed during the study in the pelagic zone of the lake (up to $10 \mu \mathrm{g} / \mathrm{dm}^{3}$ in the surface layer and up to 6 $\mu \mathrm{g} / \mathrm{dm}^{3}$ in the near-bottom layer) are comparable with those of 2006 (Gorshkov et al., 2010).

\section{Acknowledgements}

The study was carried out within the framework of the LIN SB RAS State Task No. 0345-2019-0008
Table 1. The concentration of petroleum products $(\mu \mathrm{g} /$ $\mathrm{dm}^{3}$ ) in the surface water of the pelagic zone and the average values for the basins of Lake Baikal from 30 May to 8 June 2017-2019.

\begin{tabular}{|c|c|c|c|c|}
\hline \multicolumn{2}{|c|}{ Sampling stations/year } & 2017 & 2018 & 2019 \\
\hline \multirow{2}{*}{ Southern Baikal } & West coast & 21 & 13 & 18 \\
\hline & East coast & 27 & 10 & 18 \\
\hline \multirow{2}{*}{ Central Baikal } & West coast & 17 & 10 & 6 \\
\hline & East coast & 22 & 8 & 7 \\
\hline \multirow{2}{*}{ Northern Baikal } & West coast & 17 & 9 & 8 \\
\hline & East coast & 19 & 11 & 11 \\
\hline \multirow{2}{*}{$\begin{array}{c}\text { Listvennichny } \\
\text { Cape, pelagic zone, } \\
3 \mathrm{~km} \text { from the } \\
\text { coast }\end{array}$} & $0 \mathrm{~m}$ & 12 & $<5$ & 20 \\
\hline & $50 \mathrm{~m}$ & 9 & 5 & 9 \\
\hline \multirow{2}{*}{$\begin{array}{l}\text { The Turka settle- } \\
\text { ment, pelagic zone, } \\
3 \text { from the coast }\end{array}$} & $0 \mathrm{~m}$ & 15 & 7 & 10 \\
\hline & $50 \mathrm{~m}$ & 6 & $<5$ & 6 \\
\hline \multirow{2}{*}{$\begin{array}{l}\text { Elokhin Cape, pe- } \\
\text { lagic zone, } 3 \text { from } \\
\text { the coast }\end{array}$} & $0 \mathrm{~m}$ & 27 & $<5$ & 6 \\
\hline & $50 \mathrm{~m}$ & 11 & $<5$ & $<5$ \\
\hline
\end{tabular}

(AAAA-A16-1161-22110065-4) with the support of RFBR grant No.17-29-05085 and RFBR grant No. 2045-380024.

\section{References}

Gorshkov A.G., Marinaite I.I., Zemskaya T.I. et al. 2010. The current level of oil products in the water of Lake Baikal and its tributaries. Khimiya $\mathrm{v}$ Interesakh Ustoychivogo Razvitiya [Chemistry for Sustainable Development] 18: 711-718. (in Russian)

SanPiN 2.1.4.1074-01. 2018. Drinking water. Hygienic requirements for water quality of centralized drinking water supply systems. Quality control. Hygienic requirements for provision of safety of hot water supply systems. (in Russian)

Prikaz Minsel'khoza RF No. 552 (Izmeneniya ot 12.10.2018). 2016. On the approval of water quality standards for water bodies used for fishery, including standards for maximum allowable concentrations of hazardous substances in water of water bodies used for fishery. (in Russian)

Table 2. Minimum and maximum concentrations of petroleum products $\left(\mu \mathrm{g} / \mathrm{dm}^{3}\right)$ in waters of the Baikal tributaries in different seasons from 2010 to 2019.

\begin{tabular}{|c|c|c|c|c|}
\hline Rivers & March-May & June-August & September-November & December-February \\
\hline Selenga & $5-78$ & $9-30$ & $7-10$ & $<7-19$ \\
Utulik & $13-40$ & $<5-130$ & $<5-29$ & $8-46$ \\
Solzan & $6-12$ & $<5-9$ & $<5-16$ & $<5-26$ \\
Khara-Murin & $11-52$ & $<5-68$ & $<5-16$ & $<5-19$ \\
Snezhnaya & $6-49$ & $<5-9$ & $<-16$ & $5-9$ \\
Pereyomnaya & $<5-7$ & $<5-12$ & $<5-14$ & $<5-12$ \\
Mishikha & $<5-11$ & $<5-16$ & $5-9-16$ & $<5-150$ \\
Bolshaya Cheremshanaya & $5-780$ & $<5-17$ & $5-20$ & $<-59$ \\
Malaya Cheremshanaya & $6-790$ & $<5-12$ & $<5-8$ & $<5-100$ \\
Krestovka & $<5-32$ & $<5-5$ & $<5-10$ & $5-27$ \\
Kamenushka & $11-220$ & $<5-9$ & \\
\hline
\end{tabular}

